OPEN ACCESS

Edited by: Jorge Galindo-Villegas, Murcia University, Spain

Reviewed by: Owen Kavanagh,

Queens University Belfast, UK Patricia Martínez, Universidad Autónoma Metropolitana Xochimilco, Mexico

${ }^{*}$ Correspondence: Wendy M. Sealey,

Bozeman Fish Technology Center, U.S. Fish and Wildlife Service, 4050 Bridger Canyon Road, Bozeman, MT 59715, USA wendy_sealey@fws.gov

Specialty section: This article was submitted to Immunotherapies and Vaccines, a section of the journa Frontiers in Immunology

Received: 21 May 2015 Accepted: 20 July 2015 Published: 27 August 2015

Citation:

Sealey WM, Conley ZB and

Bensley M (2015) Prebiotic supplementation has only minimal effects on growth efficiency, intestinal health and disease resistance of

Westslope cutthroat trout Oncorhynchus clarkii lewisi fed 30\% soybean meal.

Front. Immunol. 6:396. doi: 10.3389/fimmu.2015.00396

\section{Prebiotic supplementation has only minimal effects on growth efficiency, intestinal health and disease resistance of Westslope cutthroat trout Oncorhynchus clarkii lewisi fed $30 \%$ soybean meal}

\author{
Wendy M. Sealey ${ }^{1 *}$, Zachariah B. Conley ${ }^{1,2}$ and Molly Bensley ${ }^{3}$

\begin{abstract}
${ }^{1}$ Bozeman Fish Technology Center, U.S. Fish and Wildlife Service, Bozeman, MT, USA, ${ }^{2}$ Department of Animal and Range Sciences, Montana State University, Bozeman, MT, USA, ${ }^{3}$ Bozeman Fish Health Center, U.S. Fish and Wildlife Service, Bozeman, MT, USA
\end{abstract}

Prebiotics have successfully been used to prevent infectious diseases in aquaculture and there is an increasing amount of literature that suggests that these products can also improve alternative protein utilization and digestion. Therefore, the objective of this study was to examine whether prebiotic supplementation increased the growth efficiency, intestinal health, and disease resistance of cutthroat trout fed a high level of dietary soybean meal. To achieve this objective, juvenile Westslope cutthroat trout (Oncorhynchus clarkii lewisi) were fed a practical type formulation with 0 or $30 \%$ dietary soybean meal with or without the commercial prebiotic (Grobiotic-A) prior to experimental exposure to Flavobacterium psychrophilum. Juvenile Westslope cutthroat trout (initial weight $7.8 \mathrm{~g} / \mathrm{fish} \pm \mathrm{SD}$ of $0.5 \mathrm{~g}$ ) were stocked at 30 fish/tank in $75 \mathrm{~L}$ tanks with six replicate tanks per diet and fed their respective diets for 20 weeks. Final weights of Westslope cutthroat trout were affected by neither dietary soybean meal inclusion level $(P=0.9582)$ nor prebiotic inclusion $(P=0.9348)$ and no interaction was observed $(P=0.1242)$. Feed conversion ratios were similarly not affected by soybean meal level $(P=0.4895)$, prebiotic inclusion $(P=0.3258)$ or their interaction $(P=0.1478)$. Histological examination of the distal intestine of Westslope cutthroat trout demonstrated increases in inflammation due to both increased soybean meal inclusion level $(P=0.0038)$ and prebiotic inclusion $(P=0.0327)$ without significant interaction $(P=0.3370)$. Feeding dietary soybean meal level at $30 \%$ increased mortality of $F$. psychrophilum cohabitation challenged Westslope cutthroat trout $(P=0.0345)$ while prebiotic inclusion tended to decrease mortality $(P=0.0671)$. These results indicate that subclinical alterations in intestinal inflammation levels due to high dietary inclusion levels of soybean meal could predispose Westslope cutthroat trout to F. psychrophilum infection.

Keywords: cutthroat trout, soybean meal enteritis, Flavobacterium psychrophilum, prebiotic, disease resistance 


\section{Introduction}

Prebiotics are defined as non-digestible food ingredients that beneficially affect the host by stimulating growth and/or activity of a limited number of health-promoting bacteria in the intestine while limiting potentially pathogenic bacteria (1). Prebiotics have successfully been used to treat infectious diseases in aquaculture $[(2,3)$; for reviews see Ref. $(4,5)]$. More recently, there is an increasing amount of literature that suggests that these products can also improve digestion of dietary nutrients and energy in some fish species, increasing feed efficiency $(6,7)$ increasing growth $(8$, $9)$, and tempering stress responses $(10,11)$ as reviewed by Ringo et al. (12). Importantly, beneficial effects often have been observed when fish were cultured under less than optimum environmental conditions (13), when fish are exposed to pathogenic organisms (14) or when salmonids are fed alternative proteins containing anti-nutrients $(15,16)$.

Confounding additive effects of anti-nutrients in alternative proteins on gastrointestinal health have been associated with observations of reduced growth and feed efficiency in salmonids. Specifically, a wealth of information exists on detrimental effects of soybean meal on salmonid intestinal health and microbiota structure (17-24). In soybean meal-induced enteritis, the intestinal tract becomes inflamed as characterized by increased mucosal leukocyte accumulations, epithelial cell proliferation and finally enteric diarrhea when the intestine becomes inflamed (25). Decreases in immunocompetence have also been observed and are believed to be linked to the crucial immunogenic role of the hindgut of teleost fish in helping to keep the organism healthy $(26,27)$. However, a growing body of evidence suggests that hostmicrobial interactions also may result in dys-regulated mucosal immune responses (28). Even when gamete quality, genetic selection, physiochemical conditions, and nutritional requirements are well controlled or kept constant under hatchery conditions, variability among replicates has been hypothesized to be the result of detrimental fish-microbe interactions in the gut (29). The beneficial effect(s) of prebiotics in animals fed alternative protein sources also have been attributed to their ability to bind and inactivate plant antigens of glycoprotein nature and/or promoting growth of beneficial bacteria in the gastrointestinal tract of terrestrial animals $(30,31)$. Thus, microbial manipulations to improve fish health and alternative protein utilization using prebiotics have great potential even though how they mediate host benefits at the mucosal level is still poorly understood (32).

Flavobacterium psychrophilum, a gram-negative, filamentous, psychrotrophic bacterium belonging to the phylum Bacteroidetes, is the causative agent of bacterial cold-water disease (BCWD) and rainbow trout fry syndrome. F. psychrophilum is considered one of the most important salmonid pathogens worldwide (33) because of the severe mortalities caused by infection with this pathogen and the resulting economic impact among commercial aquaculture producers and conservation hatcheries (34). Laboratory studies have shown that BCWD can be spread horizontally from fish to fish $(35,36)$. However, it is believed that horizontal transmission is much greater when there is a predisposing condition that damages the mucosal barriers of the skin
(36). More recent research by Evenhuis and Cleveland (37) has demonstrated that other mucosal barriers also display upregulated immune responses during $F$. psychrophilum infection. In that study, measurable changes in gene expression for a number of innate immune molecules were up-regulated in intestinal tissue of rainbow trout following intramuscular injection challenge with F. psychrophilum (37).

Previous research in our laboratory demonstrated that normal growth rates in Snake River cutthroat trout (Oncorhynchus clarkia behnkei) fed $30 \%$ soybean meal in a 10 -week feeding trial (38). However, the histopathology data in that study demonstrated soy-level-dependent negative effects on gut health similar to that previously observed for juvenile trout $(39,40)$. Because the gastrointestinal damage of cutthroat trout previously observed in our laboratory could alter the crucial role of physical and immunological barrier that trout gastrointestinal mucosal surfaces could play in horizontal transmission of BCWD, the purpose of the current study was to examine whether prebiotic supplementation increased the growth efficiency, intestinal health and thereby disease resistance of cutthroat trout fed 30\% dietary soybean meal.

\section{Materials and Methods}

\section{Experimental Animals}

Juvenile Westslope cutthroat trout (approximately $4 \mathrm{~g}$ initial weight) were obtained from Montana Department of Fish, Wildlife and Parks' Washoe Park Trout Hatchery, Anaconda, Montana. Fish were stocked into $200-\mathrm{L}$ tanks, supplied with $14^{\circ} \mathrm{C}$ flowthrough spring water and fed a commercially produced 2-mm sinking feed (Classic Fry; Skretting North America, Tooele, UT, USA) until feeding trial initiation. All fish were handled and treated in accordance with the USFWS procedures according to the Guidelines for Use of Fishes in Research (41).

\section{Diet Formulation and Production}

A practical-type diet was formulated to meet or exceed the nutrient requirement of juvenile rainbow trout $(42,43)$. The diet was formulated to contain approximately $41 \%$ digestible protein and $15 \%$ crude lipid with fish meal, and chicken concentrate meal as the primary protein sources (Table 1). Test diets were formulated to include 0 or $30 \%$ soybean meal (SBM) with reciprocal reductions in fish meal and chicken concentrate on an equivalent digestible protein basis using rainbow trout digestible protein values (44) and 0 or $2 \%$ functional yeast product (GrobioticA, International Ingredient Company). All diets were supplemented with crystalline methionine, lysine, and threonine to the ideal amino acid targets of $3.8,1.3$, and $2.1 \%$, respectively; total phosphorus was brought to $1.2 \%$ through the addition of monocalcium phosphate. Prior to mixing, all ingredients were ground using an air-swept pulverizer (Jacobsen 18H, Minneapolis, MN, USA). Dry ingredients were mixed in a horizontal paddle mixer (Marion Mixers, Marion, Iowa) and a portion $(\sim 1 / 3)$ of the added oil was mixed into the dry ingredients along with the lecithin. The mash was then extruded through a 3.0$\mathrm{mm}$ die of a Buhler twin-screw cooking extruder (DNDL-44, Buhler AG, Uzwil, Switzerland). Barrel temperature averaged 
TABLE 1 | Composition (\% dry matter) of the experimental formulation fed to juvenile Westslope cutthroat trout.

\begin{tabular}{|c|c|c|c|c|}
\hline \multirow{2}{*}{$\begin{array}{l}\text { Ingredient } \\
\text { Soybean meal }\end{array}$} & \multicolumn{2}{|c|}{$\begin{array}{l}\text { Fish meal } \\
(0 \% \text { SBM) }\end{array}$} & \multicolumn{2}{|c|}{$\begin{array}{c}\text { Soybean meal } \\
\text { (30\% SBM) }\end{array}$} \\
\hline & 0.0 & 0.0 & 30.0 & 30.0 \\
\hline Grobiotic-A & 0.0 & 2 & 0.0 & 2 \\
\hline Wheat flour ${ }^{d}$ & 31.35 & 29.35 & 13.95 & 11.95 \\
\hline Sardine meal ${ }^{\mathrm{C}}$ & 25.0 & 25.0 & 12.0 & 12.0 \\
\hline Chicken concentrate $^{\mathrm{b}}$ & 17.0 & 17.0 & 8.0 & 8.0 \\
\hline Menhaden fish oil ${ }^{\mathrm{e}}$ & 8.2 & 8.2 & 9.3 & 9.3 \\
\hline Poultry fat & 0.0 & 0.0 & 1.6 & 1.6 \\
\hline Corn protein concentrate ${ }^{f}$ & 4.0 & 4.0 & 4.0 & 4.0 \\
\hline Spirulina ${ }^{g}$ & 3.0 & 3.0 & 3.0 & 3.0 \\
\hline Squid meal ${ }^{\mathrm{h}}$ & 3.0 & 3.0 & 3.0 & 3.0 \\
\hline Lecithin & 2.0 & 2.0 & 2.0 & 2.0 \\
\hline Stay-C $35^{i}$ & 0.2 & 0.2 & 0.2 & 0.2 \\
\hline Vitamin premix $\mathrm{ARS}^{\mathrm{j}}$ & 1.0 & 1.0 & 1.0 & 1.0 \\
\hline TM ARS $640^{k}$ & 0.1 & 0.1 & 0.1 & 0.1 \\
\hline Astaxanthin' & 0.05 & 0.05 & 0.05 & 0.05 \\
\hline Taurine $^{m}$ & 0.5 & 0.5 & 0.5 & 0.5 \\
\hline Choline Cl 50\% & 1.0 & 1.0 & 1.0 & 1.0 \\
\hline Monocalcium phosphate & 1.0 & 1.0 & 3.0 & 3.0 \\
\hline DL-Methionine & 0.5 & 0.5 & 0.85 & 0.85 \\
\hline Lysine $\mathrm{HCl}$ & 1.6 & 1.6 & 3.2 & 3.2 \\
\hline Threonine & 0.5 & 0.5 & 1.25 & 1.25 \\
\hline
\end{tabular}

${ }^{a}$ Archer Daniels Midland Company, $472 \mathrm{~g} / \mathrm{kg}$ crude protein.

${ }^{b}$ IDF Inc., $832 \mathrm{~g} / \mathrm{kg}$ protein.

c Peruvian prime sardine, Skretting, $649 \mathrm{~g} / \mathrm{kg}$ crude protein

${ }^{d}$ Manildra Milling, $120 \mathrm{~g} / \mathrm{kg}$ protein.

${ }^{\text {e} O m e g a ~ P r o t e i n s ~ I n c ., ~ V i r g i n i a ~ P r i m e ~ m e n h a d e n ~ o i l . ~}$

${ }^{f}$ Cargill Inc., Empyreal 75, $756 \mathrm{~g} / \mathrm{kg}$ crude protein.

${ }^{g}$ Earthrise, $620 \mathrm{~g} / \mathrm{kg}$ crude protein.

${ }^{h}$ Antarctic Sea Fisheries, FN Betanzos, $638 \mathrm{~g} / \mathrm{kg}$ crude protein.

'Stay-C, 35\%, DSM Nutritional Products.

${ }^{j}$ Contributed per kg of diet: vitamin A (as retinol palmitate), 30,000 IU; vitamin $D_{3}, 2160 \mathrm{IU}$; vitamin E (as dl-\%-tocopheryl-acetate), $1590 \mathrm{U}$; niacin, $990 \mathrm{mg}$; calcium pantothenate, $480 \mathrm{mg}$; riboflavin, $240 \mathrm{mg}$; thiamin mononitrate, $150 \mathrm{mg}$; pyridoxine hydrochloride, $135 \mathrm{mg}$; menadione sodium bisulfate, $75 \mathrm{mg}$; folacin, $39 \mathrm{mg}$; biotin, $3 \mathrm{mg}$; vitamin $B_{12}$, $90 \mu \mathrm{g}$.

${ }^{k}$ Contributed in mg/kg of diet: zinc, 37; manganese, 10; iodine, 5; copper, 3; selenium, 0.4 .

'DSM Nutritional Products, Carophyl Pink 10 (10\% active astaxanthin).

${ }^{m}$ NB Group Co. LTD.

$124^{\circ} \mathrm{C}$ in Sections $2-6$. Die pressure varied from 34 to 47 bar $(3,400-4,700 \mathrm{kPa})$, depending on diet. Feed had a barrel residence time of approximately $13 \mathrm{~s}$. Diets were dried in a pulse bed drier extruder (Buhler AG, Uzwil, Switzerland) with air discharge temperature remaining below $104^{\circ} \mathrm{C}$, and final moisture content $<8 \%$. After diets were dried, they were top-coated with the remaining oil at ambient pressure, and stored at room temperature $\left(\sim 18-23^{\circ} \mathrm{C}\right)$.

\section{Growth Trial}

Westslope cutthroat trout had an initial weight of $7.8 \mathrm{~g} /$ fish $( \pm 0.5 \mathrm{~g})$ and were counted into groups (30 fish) and placed into 75-L tanks. The four treatments were randomly allocated, with six replicate tanks per treatment, for a total of 24 experimental tanks. Each tank was supplied with constant temperature water $\left(14^{\circ} \mathrm{C} \pm 2\right)$ at a flow rate of $8 \mathrm{~L} / \mathrm{min}$. Photoperiod was maintained at a constant $13 \mathrm{~h}$ light and $11 \mathrm{~h}$ dark with fluorescent lighting. Fish in the trial were bulk-weighed and counted every 4 weeks, and growth rates and feed conversion ratios were calculated according to the following formulae:

$$
\begin{aligned}
\text { Weight gain }(\% \text { increase })=\frac{\begin{array}{l}
\text { Final fish weight }(\mathrm{g})- \\
\text { initial fish weight }(\mathrm{g})
\end{array}}{\text { Initial fish weight }(\mathrm{g})} \times 100 \\
\text { Feed conversion ration }(\mathrm{FCR})=\frac{\text { Feed intake }[\text { dry weight }(\mathrm{g})]}{\text { Weight gain [wet weight }(\mathrm{g})]}
\end{aligned}
$$

At the conclusion of the feeding trial, fish from each tank were randomly selected and the gastrointestinal tract was examined histologically for cellular changes related to dietary modifications. Two fish from each of the six replicate tanks were euthanized and a section measuring approximately $2 \mathrm{~cm}$ was dissected from the anterior portion of the distal intestine of each fish. Samples were preserved in Dietrich's solution until processed by standard histological procedures (45).

Since feeding of high levels of soybean meal is known to cause severe lesions in the distal intestine of Atlantic salmon, and to a lesser degree rainbow trout, histological evaluation focused on the anterior portion of the distal intestine. Two sections, taken at different depths, of intestine were examined for each fish. Based on results of previous diet studies, sections were evaluated for general cellular changes and the presence of the following alterations: inflammation and increased thickness of the stratum granulosum layer, lamina propria, or connective tissue. Observed cellular changes recorded for each fish were scored on a scale of $0-4$ : $0=$ no change; $1=$ minimal; $2=$ mild; $3=$ moderate; and $4=$ marked. In all specimens the presence of fecal material during preservation and processing resulted in tissue artifact that prevented an adequate evaluation of mucosal fold height or supranuclear vacuolization in mucosal epithelial cells.

\section{Disease Trial}

After 20 weeks of feeding of respective diets, a subsample of remaining fish from each tank were experimentally exposed to live F. pyschrophilum; Twenty fish were randomly selected and 10 fish in each tank had their dorsal fins clipped and were subcutaneously injected with $10 \mu \mathrm{L}$ of $F$. psychrophilum suspended in $0.85 \%$ saline for a dose of $6.25 \times 10^{7} \mathrm{cfu} /$ fish (46). This challenge protocol produces a clinical disease similar in presentation to a natural infection and has been reported as an appropriate model infection (47). The remaining 10 fish in each tank were sham injected with $10 \mu \mathrm{L}$ of $0.85 \%$ saline to assess effects of infection due to cohabitation. During the challenge trial, Westslope cutthroat trout were cultured as previously described and mortalities and/or moribund fish were recorded daily for 42 days post challenge ( 14 days postcessation of mortality). A minimum of $20 \%$ of the daily mortalities were re-examined and confirmed positive by detection of $F$. $p s y$ chrophilum in kidney imprints using the FITC-labeled MAb FL43.

\section{Statistical Analyses}

The PROC MIXED procedure, SAS Software Version 7.00 (SAS institute, Inc., Cary, NC, USA) was used to conduct a factorial analysis of variance for a mixed effects model (48) in which soy level and prebiotic inclusion were defined as fixed effects 
and tanks within treatments were defined as a random effect. For all analyses, binomial data were transformed using arcsine transformation prior to analysis. Differences within main effects were determined using the Tukey procedure for pair-wise comparisons (49).

\section{Results}

\section{Growth}

Final weights of Westslope cutthroat trout were affected by neither dietary soybean meal inclusion level $(P=0.9582)$ nor prebiotic inclusion $(P=0.9348)$ and no interaction was observed $(P=0.1242$; Table 2). Westslope cutthroat trout growth increase ranged from 380 to $400 \%$ with no significant effects of soybean meal level $(P=0.4526)$, prebiotic inclusion $(P=0.8480)$, or their interaction $(P=0.5295)$. Feed conversion ratios were similarly not affected by soybean meal level $(P=0.4895)$, prebiotic inclusion $(P=0.3258)$ or their interaction $(P=0.1478)$. Survival of Westslope cutthroat trout fed all diets was acceptable, ranging from 73 to $86 \%$, and was not altered by soybean meal level $(P=0.5451)$, prebiotic inclusion $(P=0.2022)$, or their interaction $(P=0.4384)$.

\section{Intestinal Health}

Histological examination of the distal intestine of Westslope cutthroat trout fed $30 \%$ soybean meal for 20 weeks demonstrated statistically significant increases in distal intestine inflammation due to both increased soybean meal inclusion level as denoted by uppercase letters in Table $3(P=0.0038)$ and due to prebiotic inclusion as denoted by lower case letters in Table $3(P=0.0327)$ without significant interaction between the factors $(P=0.3370)$. However, no pathological lesions were observed in any fish examined. Generally histological scores of 1 and 2 are considered normal or cellular changes of no significance; 3 is transitional or intermediary, moderate cellular changes that may or may not be within the normal range depending on species, age, and sex of the fish; and 4 is indicative of pathological lesions.

\section{Disease Trial}

A dietary soybean meal level of $30 \%$ resulted in a significant increase in the mortality of cohabitated Westslope cutthroat trout $(P=0.0345)$ while prebiotic inclusion only tended $(P=0.0671)$ to decrease mortality of cohabitated fish following disease challenge (Table 4). However, no statistically significant effect of dietary soybean meal or prebiotic inclusion on Westslope cutthroat mortality following F. psychrophilum injection challenge was detected. Additionally, no significant interactive effects between soybean meal level and prebiotic supplementation on survival following experimental exposure to F. psychrophilum were observed.

\section{Discussion}

The lack of growth enhancement in Westslope cutthroat trout with prebiotic supplementation agrees with previous research by Sealey et al. (50) who demonstrated no beneficial effects of Grobiotic-A supplementation on growth and feed efficiency of rainbow trout. However, these results contrast with more recent studies that investigated the effects of inclusion of Grobiotic-A in
TABLE 2 | Growth performance and survival of Westslope cutthroat trout fed diets containing 0 or $2 \%$ Grobiotic-A with 0 or $30 \%$ soybean meal (SBM) for 20 weeks.

\begin{tabular}{lcccc}
\hline Diets & $\begin{array}{c}\text { Weight gain } \\
\text { [final average } \\
\text { fish wt (g)] }\end{array}$ & $\begin{array}{c}\text { Weight } \\
\text { gain } \\
\text { (\% increase) }\end{array}$ & $\begin{array}{c}\text { Feed } \\
\text { conversion } \\
\text { ratio }\end{array}$ & $\begin{array}{c}\text { Survival } \\
\text { (\%) }\end{array}$ \\
\hline 0\% SBM & & & & \\
0\% Grobiotic-A & 39.6 & 387 & 1.0 & 86 \\
2\% Grobiotic-A & 37.1 & 380 & 1.1 & 80 \\
30\% SBM & & & & \\
O\% Grobiotic-A & 37.1 & 388 & 1.2 & 73 \\
2\% Grobiotic-A & 39.4 & 400 & 1.0 & 79 \\
Pooled SE & 1.5 & 14 & 0.08 & 3.2 \\
P-values & & & & \\
SBM & 0.9582 & 0.4526 & 0.4895 & 0.5451 \\
Grobiotic-A & 0.9348 & 0.8480 & 0.3258 & 0.2022 \\
Grobiotic-A X SBM & 0.1242 & 0.5295 & 0.1478 & 0.4384 \\
\hline
\end{tabular}

TABLE 3 | Distal intestine inflammation of Westslope cutthroat trout fed diets containing 0 or $2 \%$ Grobiotic-A with 0 or $30 \%$ soybean meal (SBM) for 20 weeks.

\begin{tabular}{lc}
\hline Diets & Inflammation score \\
\hline 0\% SBM & \\
\% Grobiotic-A & $0.33 \mathrm{Bb}$ \\
$2 \%$ Grobiotic-A & $0.67 \mathrm{Ba}$ \\
$30 \%$ SBM & \\
O\% Grobiotic-A & $0.92 \mathrm{Ab}$ \\
2\% Grobiotic-A & $1.75 \mathrm{Aa}$ \\
Pooled SE & 0.25 \\
P-values & \\
SBM & 0.0038 \\
Grobiotic-A & 0.0327 \\
Grobiotic-A X SBM & 0.3370
\end{tabular}

Values within columns with a common letter do not differ significantly at $P<0.05$; upper case letters refer to a significant soybean meal effect while lower case letters refer to significant prebiotic effect; no significant interactions were observed.

TABLE 4 | Mortality (\%) of Westslope cutthroat trout fed diets containing 0 or $2 \%$ Grobiotic-A with 0 or $30 \%$ soybean meal (SBM) for 20 weeks and then exposed to Flavobacterium psychrophilum.

\begin{tabular}{lcc}
\hline Diets & $\begin{array}{c}\text { Injected fish } \\
\text { Mortality }\end{array}$ & $\begin{array}{c}\text { Cohabitated fish } \\
\text { Mortality }\end{array}$ \\
\hline 0\% SBM & 25.0 & $1.7 \mathrm{~B}$ \\
0\% Grobiotic-A & 41.7 & $0.0 \mathrm{~B}$ \\
2\% Grobiotic-A & & \\
30\% SBM & 48.9 & $6.9 \mathrm{~A}$ \\
O\% Grobiotic-A & 40.0 & $2.0 \mathrm{~A}$ \\
2\% Grobiotic-A & 9.4 & 1.6 \\
Pooled SE & 0.2477 & 0.0345 \\
P-values & 0.6442 & 0.0671 \\
SBM & 0.2022 & 0.3560 \\
Grobiotic-A & & \\
Grobiotic-A X SBM & & \\
\hline
\end{tabular}

Values within columns with a common letter do not differ significantly at $P<0.05$; upper case letters refer to a significant soybean meal effect; no significant prebiotic effects or interactions were observed.

rainbow trout by Azari et al. $(51,52)$ who reported significantly improved specific growth rate, condition factor, and protein efficiency ratio with prebiotic supplementation. Although reasons 
for these differences are likely multifactorial, the substantial differences in the control diets dietary protein composition and notably, the high level of fish meal used by Sealey et al. (50) may be one explanation. Plant protein diets have been reported to alter the gastrointestinal microbiota of fish and alteration in their composition has been suggested as possible cause of reduced growth in these aquatic animals (53-55). Thus, an increased level of plant-based protein sources in the studies by Azari et al. (51, 52) likely increased the ability of the prebiotic supplement to improve growth relative to the control diet in that study. Lending support for this theory is the significant increase in the anaerobic and lactic acid bacteria observed in the gastrointestinal microbial community that was detected by Azari et al. (51, 52).

In the current study, even when a more conservative fish meal inclusion level and increased plant protein inclusion (commodity grade soybean meal containing anti-nutrients at the NRC reported levels) were applied, no benefit of prebiotic supplementation on growth efficiency of cutthroat trout was detected. It is possible that the additive effects of the formulation strategy of the present study may have minimized the beneficial effects of prebiotic supplementation by minimizing shifts in gastrointestinal microbial communities previously observed when rainbow trout were fed high levels of soybean meals (39). Of note, the formulation strategy of the current study, which included the use of highly palatable ingredients provided on equivalent digestible protein levels, increased supplementation of methionine, lysine, and threonine (56), fortification of vitamins at higher than NRC (57) requirements (58), macro-mineral and inositol supplementation (59), and taurine supplementation (56) has been shown to improve rainbow trout growth performance when fed plantbased diets. Because gastrointestinal microbial community was not investigated in the current study confirmation of this theory is impossible; however, previous work in our laboratory examining the effects of dietary protein blends on gastrointestinal microbial communities supports this hypothesis (23).

The lack of effect of soybean meal on growth of cutthroat trout recapitulates the results of our previous study in cutthroat trout (38). It is generally accepted that low to moderate levels of soybean meal may be included in salmonid diets without serious negative effects on growth or feed utilization $(60,61)$ as long as diets are formulated to meet the fish's nutritional needs, but inflammatory responses of the gut still will be present (62). The soybean levels investigated in the current study demonstrated soybean meallevel-dependent negative effects on gut health similar to that previously observed for juvenile rainbow trout $(39,40)$ and more recently in cutthroat trout in our laboratory (38). Iwashita et al. (63) attributed similar effects on gut histology to soybean lectins and saponins when these anti-nutrients were included at a level equivalent to $50 \%$ SBM inclusion even though growth rate was not impaired. Thus, the inability of prebiotic supplementation to reduce the soybean meal-induced intestinal histological effects may indicate an inability of the tested prebiotic (Grobiotic-A), which is described as a mixture of partially autolyzed brewer's yeast, dairy components, and dried fermentation products, to bind and inactivate soybean meal antigens in contrast to the mechanism described for the more purified mannan oligosaccharidesbased prebiotic examined by Newman (30).
Feeding Westslope cutthroat trout dietary soybean meal at 30\% also significantly increased mortality due to F. psychrophilum following cohabitation challenge. Previously in salmonids, increased susceptibility to furunculosis (60) in soybean meal-fed fish has been linked to suppressed immune capacity $(17,25,64)$. Makesh et al. (65) recently proposed that mucosal association of IgT and IgD contribute to immediate protection of rainbow trout following anal intubation exposure to an attenuated strain of $F$. psychrophilum. Thus, it is possible that soybean meal-induced immunosuppression in the current study may have altered expression of $\operatorname{IgT}$ and $\operatorname{IgD}$ in the mucosa of the intestine and reduced survival.

The non-significant tendency $(P=0.0671)$ toward a beneficial effects of prebiotic supplementation on cutthroat trout survival following F. psychrophilum cohabitation challenge in the present study is in agreement with Sealey et al. (50) who reported that dietary Grobiotic-A improved survival of rainbow trout after experimental challenge with infectious hematopoietic necrosis virus. However, the effects of Grobiotic-A following pathogen exposure also have previously been investigated in a variety of fish species with various pathogens often with conflicting results $(3,13,66-70)$. It is thus unclear whether the lack of significant effects following injection challenge in the present study alludes to the inability of the injection challenge models to account for the importance of mucosal barrier integrity in BCWD transmission as has previously been proposed $(35,36)$ and/or bypass the prebiotic benefits of gut microbial shifts and inhibition of pathogens (71). The latter mode of prebiotic action has been described previously in rainbow trout fed Grobiotic-A $(51,52)$.

Taken together these preliminary data seem to suggest that subclinical alterations in intestinal inflammation levels due to high dietary inclusion levels of soybean meal can predispose Westslope cutthroat trout to F. psychrophilum infection. Additional corroborating research utilizing additional response variables is necessary to identify the putative mechanism(s) and methods to mitigate these effects.

\section{Acknowledgments}

The authors wish to thank Dr. Rick Barrows, Jason Frost, Carly Stone, and Nate Haygood for their assistance with diet manufacturing; Dr. Gibson Gaylord, Cal Fraser, Matt Toner, and Jason Ilgen for their assistance with fish culture and sampling; and Paige Maskill for her assistance with laboratory analyses. We would also like to thank the Bozeman Fish Health Lab staff and contractors for their collaborative efforts specifically Tammy Weiss for tissue processing and Beth MacConnell for assistance in pathology interpretation. Funding for the study was provided, in part, by the Western Regional Aquaculture Center through grant number 2012-38500-19657 from the U.S. Department of Agriculture National Institute of Food and Agriculture. Mention of trade names or commercial products in this article is solely for the purpose of providing specific information and does not imply recommendation or endorsement by the authors, the U.S. Department of Agriculture or the U.S. Fish and Wildlife Service. 


\section{References}

1. Gibson GR, Roberfroid MB. Dietary modulation of the human colonic microbiota: introducing the concept of prebiotics. J Nutr (1995) 125:1401-12.

2. Sealey WM, Gatlin DM III. Overview of nutritional strategies affecting health of marine fish. J Appl Aquacul (1999) 9:11-26. doi:10.1300/J028v09n02_02

3. Li P, Gatlin DM III. Dietary brewer's yeast and the prebiotic Grobiotic AE influence growth performance, immune response and resistance of hybrid striped bass (Morone chrysops x M. saxatilis) to Streptococcus iniae infection. Aquaculture (2004) 231:445-56. doi:10.1016/j.aquaculture.2003.08.021

4. Ringo E, Olsen RE, Gifstad TØ, Dalmon RA, Amlund H, Hemre GI, et al. Prebiotics in aquaculture: a review. Aquacult Nutr (2010) 16:117-36. doi:10. 1111/j.1365-2095.2009.00731.x

5. Gatlin DM III, Peredo AM. Prebiotics and Probiotics: Definitions and Applications. Stoneville, MS: SRAC Publication (2012). 8 p.

6. Burr G, Hume M, Ricke S, Gatlin DM III. Effects of prebiotics on nutrient digestibility of a soybean-meal based diet by red drum Scieanops ocellatus. Aquacult Res (2008) 39:1680-6.

7. Grisdale-Helland B, Helland SJ, Gatlin DM III. The effects of dietary supplementation with mannanoligosaccharide, fructooligosaccharide or galactooligosaccharide on the growth and feed utilization of Atlantic salmon (Salmo salar L.). Aquaculture (2008) 283:163-7. doi:10.1016/j.aquaculture.2008.07.012

8. Staykov Y, Spring P, Denev S, Sweetman J. Effect of a mannan oligosaccharide on the growth performance and immune status of a rainbow trout (Oncorhynchus mykiss). Aquacultu Int (2007) 15:153-61. doi:10.1007/s10499007-9096-z

9. Yilmaz E, Genc MA, Genc E. Effects of dietary mannan oligosaccharides on growth, body composition, and intestine and liver histology of rainbow trout Oncorhynchus mykiss. Isr J Aquacult (2007) 59:182-8.

10. Carnevali O, de Vivo L, Sulpizio R, Gioacchini G, Olivotto I, Silvi S, et al. Growth improvement by probiotic in European sea bass juvelines (Dicentrarchus labrax L.) with particular attention to IGF-1, myostatin and cortisol gene expression. Aquaculture (2006) 258:430-8. doi:10.1016/j.aquaculture.2006.04.025

11. Lochmann R, Sink TD, Phillips H, Chen R. Evaluation of a dietary dairyyeast prebiotic in juvenile golden shiners in ponds. N Am J Aquacult (2010) 72:164-71. doi:10.1577/A09-029.1

12. Ringo E, Dimitroglou A, Hoseinifar SH, Davies SJ. In: Merrifield DL, Ringo E, editors. Aquaculture Nutrition: Gut Health, Probiotics and Prebiotics. New York, NY: Wiley and Sons (2014). p. 360-400.

13. Sink TD, Lochmann RT. Preliminary observations of mortality reduction in stressed, Flavobacterium columnare-challenged golden shiners after treatment with dairy-yeast prebiotics. N Am J Aquacult (2008) 70:192-4.

14. Sealey WM, Barrows FT, Smith CE, Hardy RW. Dietary supplementation strategies to improve performance of rainbow trout Oncorhynchus mykiss fed plant-based diets. Bull Fish Res Agency Jpn (2010) 31:15-23.

15. Refstie S, Baeverfjord G, Seim RR, Elvebo O. Effects of dietary yeast cell wall $\beta$-glucans and MOS on performance, gut health, and salmon lice resistance in Atlantic salmon (Salmo salar) fed sunflower and soybean meal. Aquaculture (2010) 305:109-16. doi:10.1016/j.aquaculture.2010.04.005

16. Sealey WM, Barrows FT, Smith CE, Overturf K, LaPatra SE. Soybean meal level and probiotics in first feeding fry diets alter the ability of rainbow trout Oncorhynchus mykiss to utilize high levels of soybean meal during grow-out. Aquaculture (2009) 293:195-203. doi:10.1016/j.aquaculture.2009.04.013

17. Bakke-McKellep AM, Press C, Baeverfjord G, Krogdahl A, Landsverk T. Changes in immune and enzyme histochemical phenotypes of cells in the intestinal mucosa of Atlantic salmon, Salmo salar L., with soybean mealinduced enteritis. J Fish Dis (2000) 23:115-27. doi:10.1046/j.1365-2761.2000. 00218.x

18. Bakke-McKellep AM, Koppang EO, Gunnes G, Sanden M, Hemre GI. Histological, digestive, metabolic, hormonal and some immune factor responses in Atlantic salmon, Salmo salar L, fed genetically modified soybeans. J Fish Dis (2007) 30:65-70. doi:10.1111/j.1365-2761.2007.00782.x

19. Krogdahl A, Bakke-McKellep AM, Baeverfjord G. Effects of graded levels of standard soybean meal on intestinal structure, mucosal enzyme activities, and pancreatic response in Atlantic salmon, Salmon salar L. Aquacult Nutr (2003) 9:361-71. doi:10.1046/j.1365-2095.2003.00264.x

20. Sanden M, Berntssen MHG, Krogdahl A, Hemre GI, Bakke-McKellep AM. An examination of the intestinal tract of Atlantic salmon, Salmo salar L., parr fed different varieties of soy and maize. J Fish Dis (2005) 28:317-30.
21. Mansfield GS, Desai AR, Nilson SA, Van Kessel AG, Drew MD, Hill JE. Characterization of rainbow trout (Oncorhynchus mykiss) intestinal microbiota and inflammatory marker gene expression in a recirculating aquaculture system. Aquaculture (2010) 307:95-104. doi:10.1016/j.aquaculture.2010.07.014

22. Desai AR, Links MG, Collins SA, Mansfield GS, Drew MD, Van Kessel AG, et al. Effects of plant-based diets on the distal gut microbiome of rainbow trout (Oncorhynchus mykiss). Aquaculture (2012) 353:134-42. doi:10.1016/j. aquaculture.2012.04.005

23. Betiku OC, Gaylord TG, Barrows FT, Myrick C, Ross CA, Fornshell GA, et al. Alternative protein diets for rainbow trout: performance in a laboratory trial: effects of diet on gut microbial community. United States Aquaculture Society Annual Meeting. Seattle, WA (2014).

24. Ingersleve HC, von Gersdorff Jørgensen L, Lenz Strube M, Larsen N, Dalsgaard I, Boye M, et al. The development of the gut microbiota in rainbow trout is affected by first feeding and diet type. Aquaculture (2014) 424:24-34. doi:10. 1016/j.aquaculture.2013.12.032

25. Rumsey GL, Endres JG, Bowser PR, Earnest-Koons KA, Anderson DP, Siwicki AK. Soy protein in diets of rainbow trout: Effects on growth, protein absorption, gastro- intestinal histology, and non-specific serologic and immune response. In: Lim C, Sessa DJ, editors. Nutrition and Utilization Technology in Aquaculture. Champaign, IL: AOAC Press (1994). p. 166-88.

26. Ellis AE. Recent development in oral vaccine delivery systems. Fish Pathol (1995) 30:293-300. doi:10.3147/jsfp.30.293

27. Ellis AE. Innate host defense mechanisms of fish against viruses and bacteria Dev Comp Immunol (2001) 25:827-39. doi:10.1016/S0145-305X(01)00038-6

28. O'Flaherty S, Saulnier DM, Pot B, Versalovic J. How can probiotics and prebiotics impact mucosal immunity? Gut Microbes (2010) 1:293-300. doi:10.4161/ gmic.1.5.12924

29. Vadstein O, Bergh O, Gatesoupe F, Galindo-Villegas J, Mulero V, Picchietti S, et al. Microbiology and immunology in fish larvae. Rev Aquacult (2013) 5(S1):S1-25. doi:10.1111/j.1753-5131.2012.01082.x

30. Newman KE. Effect of mannan oligosaccharide on the microflora and immunoglobulin status of sows and piglet performance. J Anim Sci (2001) 79:189-201.

31. Fernandez F, Hinton M, van Gils B. Dietary mannan-oligosaccharides and their effect on chicken caecal microflora in relation to Salmonella enteritidis colonization. Avian Pathol (2002) 31:49-58. doi:10.1080/03079450120106000

32. Dimitroglou A, Merrifield DL, Carnevali O, Picchietti S, Avella M, Daniels C, et al. Microbial manipulations to improve fish health and production - a Mediterranean perspective. Fish Shellfish Immunol (2011) 30:1-16. doi:10.1016/ j.fsi.2010.08.009

33. Michel C, Antonio D, Hedrick RP. Production of viable culture of Flavobacterium psychrophilum: approach and control. Res Microbiol (1999) 150:351-8. doi:10.1016/S0923-2508(99)80061-8

34. LaFrentz BR, Cain KD. Bacterial Coldwater Disease. An Extension Bulletin for the Western Regional Aquaculture Center and Idaho and Washington Initiative Award. Seattle: Western Regional Aquaculture Center (2004). No. 9938500-7507.

35. Madsen L, Dalsgaard I. Reproducible methods for experimental infection with Flavobacterium psychrophilum in rainbow trout Oncorhynchus mykiss. Dis Aquat Organ (1999) 36:169-76. doi:10.3354/dao036169

36. Madetoja J, Nyman P, Wiklund T. Flavobacterium psychrophilum, invasion into and shedding by rainbow trout Oncorhynchus mykiss. Dis Aquat Organ (2000) 43:27-38. doi:10.3354/dao043027

37. Evenhuis JP, Cleveland BM. Modulation of rainbow trout (Oncorhynchus mykiss) intestinal immune gene expression following bacterial challenge. Vet Immunol Immunopathol (2012) 146:8-17. doi:10.1016/j.vetimm.2012.01.008

38. Ham BR, Barrows FT, Huttinger A, Duff GC, Yeoman CJ, Maskill M, et al. Evaluation of dietary soy sensitivity in Snake River Cutthroat trout. N Am J Aquacult (2015) 77:195-205. doi:10.1080/15222055.2014.993489

39. Heikkinen J, Vielma J, Kemiläinen O, Tiirola M, Eskelinen P, Kiuru T, et al. Effects of soybean meal based diet on growth performance, gut histopathology and intestinal microbiota of juvenile rainbow trout (Oncorhynchus mykiss). Aquaculture (2006) 261:259-68. doi:10.1016/j.aquaculture.2006.07.012

40. Ostaszewska T, Dabrowski K, Palacios ME, Olejniczak M, Wieczorek M. Growth and morphological changes in the digestive tract of rainbow trout (Oncorhynchus mykiss) and pacu (Piaractus mesopotamicus) due to casein replacement with soybean proteins. Aquaculture (2005) 245:273-86. doi:10. 1016/j.aquaculture.2004.12.005 
41. Use of Fishes in Research Committee (joint committee of the American Fisheries Society, The American Institute of Fishery Research Biologist, and the American Society of Ichthyologists and Herpetologsits). Guidelines for the Use of Fishes in Research. Bethesda, MD: American Fisheries Society (2004).

42. Hardy RW. Rainbow trout, Oncorhynchus mykiss. In: Webster CD, Lim CE, editors. Nutrient Requirements and Feeding of Finfish for Aquaculture. Binghamton, NY: Haworth Press, Inc. (2002). p. 184-202.

43. NRC (National Research Council). Nutrient Requirements of Fish. Washington, DC: National Academy Press (2011)

44. Gaylord TG, Barrows FT, Rawles SD. Apparent digestibility of gross nutrients from feedstuffs in extruded feed diets for rainbow trout, Oncorhynchus mykiss. J World Aquacult Soc (2008) 39:827-34. doi:10.1111/j.1749-7345.2008.00220.x

45. Sheehan D, Hrapchek B. Theory and Practice of Histotechnology. 2nd ed. Columbus, OH: Battlelle Press (1983).

46. LaFrentz BR, LaPatra SE, Jones GR, Cain KD. Protective immunity in rainbow trout, Oncorhynchus mykiss, following immunization with distinct molecular mass fractions isolated from Flavobacterium psychrophilum. Dis Aquat Organ (2004) 59:17-26. doi:10.3354/dao059017

47. LaFrentz BR, LaPatra SE, Jones GR, Cain KD. Passive immunization of rainbow trout, Oncorhynchus mykiss (Walbaum), against Flavobacterium psychrophilum, the causative agent of bacterial coldwater disease and rainbow trout fry syndrome. J Fish Dis (2003) 26:371-84. doi:10.1046/j.1365-2761.2003.00468.x

48. Ott L. An Introduction to Statistical Methods and Data Analysis. North Scituate, MA: Duxbery Press (1977).

49. Tukey J. The Problem of Multiple Comparisons. Princeton, NJ: Princeton University (1953).

50. Sealey WM, Barrows FT, Hang A, Johansen KA, Overturf K, LaPatra S, et al. Evaluation of the ability of partially autolyzed yeast and Grobiotic-A to improve disease resistance of rainbow trout. N Am J Aquacult (2007) 69:400-6. doi:10. 1577/A06-080.1

51. Azari AH, Hashim R, Habibi Rezaei M, Sharifzadeh Baei M, Najafpour S, Roohi $A$, et al. The effects of commercial probiotic and prebiotic usage on growth performance, body composition and digestive enzyme activities in juvenile rainbow trout (Oncorhynchus mykiss). World Appl Sci J (2011) 14:26-35.

52. Azari AH, Hashim R, Azari Takami G, Farabi SMV, Darvish M, Safari R. Effect of (GroBiotic $\left.{ }^{\circledR}-\mathrm{A}\right)$ on the growth performance and intestinal microflora on rainbow trout (Oncorhynchus mykiss Walbaum). J Res Biol (2011) 1:325-34.

53. Ringo E, Olsen RE. The effect of diet on aerobic bacterial flora associated with intestine of Arctic charr (Salvelinus alpinus L.). J Appl Microbiol (1999) 86:22-8. doi:10.1046/j.1365-2672.1999.00631.x

54. Olsen RE, Sundell K, Mayhew TM, Myklebust R, Ringø E. Acute stress alters intestinal function of rainbow trout, Oncorhynchus mykiss (Walbaum). Aquaculture (2005) 250:480-95.

55. Ringo E, Sperstad S, Mklebust R, Refstie S, Krogdahl A. Characterization of the microbiota associated with intestine of Atlantic cod (Gadus morhua L.): The effect of fish meal, standard soybean meal and a bioprocessed soybean meal. Aquaculture (2006) 261:829-41. doi:10.1016/j.aquaculture.2006.06.030

56. Gaylord TG, Barrows FT. Multiple amino acid supplementations to reduce dietary protein in plant-based rainbow trout, Oncorhynchus mykiss, feeds. Aquaculture (2009) 287:180-4. doi:10.1016/j.aquaculture.2008.10.037

57. NRC (National Research Council). Nutrient Requirements of Fish. Washington, DC: National Academy Press (1993).

58. Barrows FT, Gaylord TG, Sealey WM, Smith CE, Porter L. The effect of vitamin premix in extruded plant based and fish meal based diets on growth efficiency and health of rainbow trout, Oncorhynchus mykiss. Aquaculture (2008) 283:148-55. doi:10.1016/j.aquaculture.2008.07.014

59. Barrows FT, Gaylord TG, Sealey WM, Porter L, Smith CE. Supplementation of plant-based diets for rainbow trout (Oncorhynchus mykiss) with macro-minerals and inositol. Aquacult Nutr (2010) 16:654-61. doi:10.1111/j. 1365-2095.2009.00717.x

60. Krogdahl A, Bakke-McKellep AM, Røed KH, Baeverfjord G. Feeding Atlantic salmon Salmo salar L. soybean products: effects on disease resistance (Furunculosis), and lysozyme and IgM levels in the intestinal mucosa. Aquacult Nutr (2000) 6:77-84. doi:10.1046/j.1365-2095.2000.00129.x

61. Refstie S, Korsoen OJ, Storebakken T, Baeverfjord G, Lein I, Roem AJ. Differing nutritional responses to dietary soybean meal in rainbow trout (Oncorhynchus mykiss) and Atlantic salmon (Salmo salar). Aquaculture (2000) 190:49-63. doi: 10.1016/S0044-8486(00)00382-3

62. Baeverfjord G, Krogdahl A. Development and regression of soybean meal induced enteritis in Atlantic salmon, Salmo salar L., distal intestine: a comparison with the intestines of fasted fish. J Fish Dis (1996) 19:375-87. doi:10.1111/ j.1365-2761.1996.tb00376.x

63. Iwashita Y, Yamamoto T, Furuita H, Sugita T, Suzuki N. Influence of certain soybean anitnutritional factors supplemented to casein-based semipurified diet on intestinal and liver morphology in fingerling rainbow trout Oncorhynchus mykiss. Fisheries Sci (2008) 74:1075-82. doi:10.1111/j.1444-2906.2008.01627.x

64. Burrells C, Williams PD, Southgate PJ, Crampton VO. Immunological, physiological and pathological responses of rainbow trout (Oncorhynchus mykiss) to increasing dietary concentration of soybean proteins. Vet Immunol Immunopathol (1999) 72:277-88. doi:10.1016/S0165-2427(99)00143-9

65. Makesh M, Ponnerassery SS, Cain KD. Systemic and mucosal immune response of rainbow trout to immunization with an attenuated Flavobacterium psychrophilum vaccine strain by different routes. Fish Shellfish Immunol (2015) 44:156-63. doi:10.1016/j.fsi.2015.02.003

66. Li P, Gatlin DM III. Evaluation of the prebiotic GroBiotic ${ }^{\circledR}-\mathrm{A}$ and brewers yeast as dietary supplements for sub-adult hybrid striped bass (Morone chrysops $\times M$. saxatilis) challenged in situ with Mycobacterium marinum. Aquaculture (2005) 248:97-205. doi:10.1016/j.aquaculture.2005.03.005

67. Sink TD, Lochmann RT, Goodwin AE, Marecaux E. Mortality rates in golden shiners fed high-fat diets with or without a dairy-yeast prebiotic before challenge with Flavobacterium columnare. N Am J Aquacul (2007) 69:305-8. doi:10. 1577/A06-078.1

68. Savolainen LC, Gatlin DM III. Evaluation of dairy-yeast prebiotic supplementation in the diet of juvenile goldfish in the presence or absence of phytoplankton and zooplankton. J Anim Health. (2009) 21:156-63. doi:10.1577/H08-063.1

69. Buentello AJ, Neill WH, Gatlin DM III. Effects of dietary prebiotics on growth, feed efficiency and non-specific immunity of juvenile red drum Sciaenops ocellatus fed soybean-based diets. Aquacult Res (2010) 41:411-8. doi:10.1111/ j.1365-2109.2009.02178.x

70. Zheng ZL, Wang KY, Gatlin DM III, Ye JM. Evaluation of the ability of GroBiotic $^{\circledR}$-A to enhance growth, muscle composition, immune responses, and resistance against Aeromonas hydrophila in Nile tilapia, Oreochromis niloticus. $J$ World Aquacult Soc (2011) 42:549-56. doi:10.1111/j.1749-7345.2011.00497.x

71. Steed H, Macfarlane S. Mechanisms of prebiotic impact on health. In: Charalampopoulos D, Rastall RA, editors. Prebiotics and Probiotics Science and Technology. New York, NY: Springer (2009). p. 135-61.

Conflict of Interest Statement: The authors declare that the research was conducted in the absence of any commercial or financial relationships that could be construed as a potential conflict of interest.

Copyright (c) 2015 Sealey, Conley and Bensley. This is an open-access article distributed under the terms of the Creative Commons Attribution License (CC BY). The use, distribution or reproduction in other forums is permitted, provided the original author(s) or licensor are credited and that the original publication in this journal is cited, in accordance with accepted academic practice. No use, distribution or reproduction is permitted which does not comply with these terms. 